\title{
A Review of Forest Management Effects on Terrestrial Leaf Litter Inhabiting Arthropods
}

\author{
Jess Hartshorn
}

check for updates

Citation: Hartshorn, J. A Review of Forest Management Effects on Terrestrial Leaf Litter Inhabiting Arthropods. Forests 2021, 12, 23. https://dx.doi.org/10.3390/f12010023

Received: 5 November 2020

Accepted: 25 December 2020

Published: 28 December 2020

Publisher's Note: MDPI stays neutral with regard to jurisdictional claims in published maps and institutional affiliations.

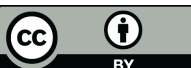

Copyright: (C) 2020 by the author. Licensee MDPI, Basel, Switzerland. This article is an open access article distributed under the terms and conditions of the Creative Commons Attribution (CC BY) license (https: / / creativecommons.org / licenses/by/4.0/).
Department of Forestry and Environmental Conservation, Clemson University, Clemson, SC 29634, USA; jhartsh@clemson.edu

\begin{abstract}
Leaf litter arthropods are some of the most abundant and diverse communities in forests and provide myriad ecosystem services from decomposition and mineralization to pollination and predation. They are important to forest health and management and, in turn, are affected by how we manage our forests. Various forest management techniques such as clear cutting, burning, and chemical control of invasive species all have differing effects on ground dwelling arthropods and, despite their importance, a review of the literature on these effects does not currently exist. My objective with this paper is to review the effects of different types of forest management on arthropods in leaf litter systems.
\end{abstract}

Keywords: leaf litter; forest management; arthropods

\section{Introduction}

Leaf litter-dwelling arthropods (Table 1) are some of the most prominent components of ecosystems in terms of both biomass and diversity [1,2]. They are critical parts of forested ecosystems [3-5] due to the wide breadth of ecosystem services they provide. Namely, litter-inhabiting arthropods act as predators [6-10], decomposers of organic matter [11,12] and serve to mineralize certain nutrients into the soil [13]. Feeding by these arthropods stimulates microorganism growth [14] and also adds fecal matter to the substrate [15]. Some arthropods that inhabit leaf litter, like termites and ants, are even considered "ecosystem engineers" due to their important effects on the ecosystem [16-18].

Table 1. Arthropods commonly encountered in forest leaf litter.

\begin{tabular}{ccc}
\hline Class & Order & Family \\
\hline Arachnida & Acari & Ixodidae \\
& Oribatida \\
& Araneae & Gnaphosidae \\
& & Lycosidae \\
& & Salticidae \\
& Theridiidae \\
& Opiliones & \\
Crustacea & Pseudoscorpionida & \\
& Amphipoda & \\
Chilopoda & Decapoda & \\
Diplopoda & Isopoda & \\
Hexapoda & & Cantharidae \\
& Coleoptera & Carabidae \\
& & Chrysomelidae \\
& & Curculionidae \\
\hline
\end{tabular}


Table 1. Count.

\begin{tabular}{ccc}
\hline Class & Order & Family \\
\hline & & Elateridae \\
& Histerida \\
& Psephalidae \\
& Ptilodatilidae \\
& Scydmaenidae \\
& Staphylinidae \\
Collembola & Tenebrionidae \\
Dermaptera & \\
Diplura & \\
Diptera & Muscidae \\
& Simuliidae \\
Orthoptera & Gryllidae \\
Hemiptera & Cercopidae \\
& Cicadellidae \\
& Pentatomidae \\
Hymenoptera & Formicidae \\
& Microhymenoptera \\
Lepidoptera & Geomteridae \\
& Noctuidae \\
\hline
\end{tabular}

Due to their phylogenetic and functional diversity, leaf litter arthropods can have significant impacts on other trophic levels as well [19]. For example, leaf litter composition has been shown to alter the alkaloid profiles of litter-dwelling ants which then impacts the chemical defenses of poison frogs which feed on these ants [20]. Leaf litter-dwelling arthropods have also been developed as bioindicators of ecosystem and soil health [5,21-24]. Some ground dwelling taxa, like beetles (Coleoptera) and spiders (Araneae), are very sensitive to habitat modifications $[25,26]$ and forest management both directly and indirectly impacts these groups more than others.

Forest management impacts on arthropod groups also differs according to place of origin. Most studies on this subject have been done in tropical systems [27-30], however, studies from Europe [23] and North America [31,32] also exist and shed light on the different impacts of forest management in temperate forests. For instance, arthropods in tropical systems tend to decline in relation to forest harvests and altered land use-for example, urbanization - while temperate systems see increases in arthropod diversity in these situations [33]. These effects are taxa dependent, however. Acari, especially oribatid mites, respond positively to a moderate degree of urbanization while Collembola [34] and Diplopoda [35] respond negatively to all levels of urbanization. Responses may also be specific to plant species, as others have found differences in diversity and abundance of Collembola by leaf litter type, regardless of management or land-use practice [36]. High diversity in places like urban forests does not necessarily translate to high diversity in surrounding areas. Man-made barriers like roads and sidewalks form a substantial disruption to the dispersal of arthropods in these systems, so diversity in these scenarios is likely patchy and inconsistent [37].

While forest management type and regionality affects the intensity and directionality of impacts to arthropods, some general trends do exist. For example, contrary to some beliefs, plantation forestry does support leaf litter arthropod biodiversity [38,39], and arthropods are resilient to both site preparation [40] and harvesting practices [41]. However, many of these interactions are taxa dependent, with mobile species being affected differently than sessile species [42]. For example, community composition of winter-active spiders in plantation forests differed based on plantation species and whether it was native to the region [43]. My objectives with this paper are to review the effects of different types 
of forest management on leaf litter arthropods and to outline gaps in knowledge with regards to ground-dwelling arthropods in forested systems.

To assess the available literature on forest management practices and their effects on leaf litter-dwelling arthropods, I used Google Scholar and ISI Web of Knowledge to search for "leaf litter", "arthropods", and "forest management" as well as combinations of these terms. Articles were considered acceptable if they quantified leaf litter arthropods and detailed the type of forest management used (e.g., clear-cut, slash management). Articles that investigated the impacts of arthropods on forest productivity, as well as articles evaluating soil arthropods, were not included in this review.

\section{Effects of Forest Harvesting}

Forest management is frequently done in such a way as to mimic natural disturbances like fire, insect outbreaks, or hurricanes [44]. Natural disturbances may occur frequently and create partial-stand clearings, resulting in a mosaic of stand types and ages. Natural disturbances may also occur as whole-stand replacing events [45]. Forest management affects microclimates of the forest floor through altering light availability, wind, temperature, and moisture, thereby indirectly affecting the arthropods that inhabit the leaf litter [46].

Harvest methods which mimic large disturbances (e.g., clear-cuts, gap cuts) create significant amounts of edge habitats which tend to have more extreme microclimates [47] and support a lower abundance of leaf litter arthropods [48]. Clear cuts also increase the temperature extremes of the forest floor and remove organic matter inputs, both of which negatively impact leaf litter arthropods [49]. Compared to unforested habitats, however, forests may have lower diversity [50] and more clustered phylogenetic relationships of leaf litter communities [32]. Single-tree selection also has significant impacts on some leaf litter dwelling arthropods and has been found to shift carabid communities towards those more associated with grassland habitats, even without substantial tree removal [51].

In addition, soil compaction from logging equipment results in a reduction in arthropod diversity [52]. In intensively managed forests like oil palm plantations, abundance and diversity of leaf litter arthropods was significantly lower compared to untouched forests [53]. Forest harvesting may also have positive effects on leaf litter arthropod communities, however. Ground-dwelling arthropods are more abundant near course woody debris that is left over from harvest operations [31,54]. This increase in course woody debris may explain observed increases in functional diversity of ants, specifically [55].

While some information is known on the impacts of forest management on leaf litter arthropods, little is known on how specific operations (e.g., single-tree selection, gap harvests) affects individual groups or their interactions. There is also little known about how arthropod communities respond to forest harvests over time or how their responses compare to that of natural disturbances.

\section{Effects of Forest Restoration}

Rainforest restoration presents unique forest management challenges with a variety of techniques available [56,57], and some ground-dwelling groups, like ants, have been developed as biological indicators of the progress of restoration efforts [29,30]. While restoration methods undoubtedly affect leaf litter arthropods, little has been done to examine the effects of these efforts on said communities.

In general, decomposers are less abundant in anthropogenic sites that have been cleared for pasture or other agricultural use [58,59]. However, some authors have found no differences among certain communities, such as ants, among primary forests and forests disturbed for agricultural uses [60]. Also, increased amounts of detritus leads to higher abundance of all arthropod feeding guilds in leaf litter communities, indicating that there are bottom-up limitations in rainforests [19]. These limitations have implications for methods of restoration in degraded rainforests. For example, reforestation efforts that lead to greater structural diversity of plant life likely lead to greater diversity of leaf litter as well. This diversity creates a wide range of microclimates which are beneficial to many ground-dwelling beetles [61]. 
Compared to other restoration methods, island plantations most closely resembled untouched forests, however, leaf litter arthropods recovered eight years post-harvest even with no restoration [27]. In contrast, methods such as brushwood transposition, wherein woody material is transported to the damaged area to create a heterogenous environment, had low leaf litter arthropod diversity [62]. In North America, second-growth forests support highly diverse populations of leaf-litter inhabiting beetles $[63,64]$ indicating considerable resilience to forest harvesting and conservation efforts.

It is of paramount importance to keep in mind that not all arthropod species are affected in the same ways by these restoration efforts. For example, common species appear to be unaffected while rarer species are more effected by both deforestation and reforestation [65]. Considering the amazing biodiversity of arthropods in rainforests, the effects on rare species are highly concerning. There are significant gaps in knowledge regarding what those rare species are, how they interact with more common species, and how these transition periods of reforestation affect them.

\section{Invasive Species Control}

Control of forest pests often involves intense management including sanitation harvests and chemical control. In general, control of invasive species negatively impacts leaf litter arthropod communities, although in different ways. As previously mentioned, sanitation harvests, which are often clear cuts, negatively impact leaf litter dwelling arthropod communities through an increase in forest floor temperatures and a reduction in organic matter inputs [49]. Chemical control also impacts arthropods on the forest floor. For example, diflubenzuron, a commonly used chemical control of the invasive gypsy moth, caused reductions in mites, thrips, centipedes and spiders $[3,66]$.

A lack of invasive species control also impacts ground dwelling arthropods in the leaf litter. For example, increased ash wood on the ground from emerald ash borer (EAB) infestation causes increases in leaf litter arthropods [67]. Tree-killing invasive insects, like EAB, may also result in changes to leaf litter-dwelling arthropod communities by temporarily increasing the litterfall input, which is then followed by significant light gaps in the canopy [68]. Invasive plants may represent an initial pulse of novel resources for leaf litter arthropods, thereby showing some benefit early on. However, following decomposition, there is an overall negative effect of invasive plants on leaf litter arthropods [69].

There are several significant gaps in knowledge with regards to invasive species control and leaf litter arthropods. The current literature mainly covers the effects of chemicals or impacts of the invasive species itself on leaf litter arthropod groups. However, there is little known about how leaf litter affects the resiliency of forests to invasive pests or how invasive plants affect these communities.

\section{Effects of Fire}

Compared to logging operations, fire has a much bigger impact on leaf litter arthropods [70]. Fire has been used for thousands of years by indigenous peoples around the world in agricultural, forest, and wildlife management [71-74]. Decades of fire suppression has led to an increase in fuel load and significant changes to the landscape, such as loss of dominant fire-dependent species, and there have been recent efforts to get fire back on the ground and reincorporated as an essential part of forest management [75]. Fire has complex effects on leaf litter arthropods through the creation of more structurally diverse habitats [76,77] and through changes to the forest floor microclimate [78]. Fire increases temperature and changes soil $\mathrm{pH}$, as well as fluctuations in soil moisture [79]. The exposure to extreme temperatures, increased light, and reduced moisture frequently result in habitat loss [80], especially for those fire-intolerant species that are prone to inhabiting midand late-successional forests [81,82]. Changes to plant communities through fire can also modify soil moisture, invariably affecting ground-dwelling arthropods [83].

Fire, like harvesting operations and invasive species control, impacts different taxa in different ways [84-86]. For example, species richness of beetles increased following fire in 
the Sierra Nevada mountain range, but the intensity and directionality of impacts were taxon specific with no general patterns [87]. Some general patterns have emerged, however, from the literature. There is typically a significant, immediate reduction in arthropod abundance following fire $[28,88,89]$. These communities, however, appear to be resilient to fire $[86,90-95]$ and abundance and diversity of leaf litter arthropods actually increases following burning $[96,97]$.

Leaf litter arthropods also have complicated relationships with fungi [98] and fire has been shown to reduce total fungal biomass in forests [99]. Arthropod feeding on senescent hyphal structures of fungi stimulates fungal growth [97], and the presence of leaf litter decomposing arthropods is significantly related to mycorrhizal growth in some tree species like red maple [14].

While it is known that fire has significant effects on leaf litter dwelling arthropods, there is a significant gap in knowledge as to how various arthropod characteristics affect their interactions with fire. How different environmental and landscape characteristics affect leaf litter following a burn and what this means for associated arthropod communities remains unexplored.

\section{Conclusions}

While we have determined some general trends of effects of forest management on leaf litter arthropods, there is still much to uncover. Arthropods are most definitely affected by forest management activities, but appear to be resilient to these human activities. However, it is unknown how specific types of management affect specific taxa, and this is important from the standpoint of monitoring overall forest health. More work is necessary to understand how various types of forest management affect specific groups like beetles, spiders, ants, and other bioindicators.

Funding: This research received no external funding.

Acknowledgments: I would like to acknowledge Mike Ferro, Clemson University, for his thoughtful edits on this paper as well as the constructive comments from two anonymous reviewers.

Conflicts of Interest: The author declares no conflict of interest.

\section{References}

1. Anderson, J.M. Succession, Diversity and Trophic Relationships of some Soil Animals in Decomposing Leaf Litter. J. Anim. Ecol. 1975, 44, 475. [CrossRef]

2. Stork, N.E.; Blackburn, T.M. Abundance, Body Size and Biomass of Arthropods in Tropical Forest. Oikos 1993, 67, 483. [CrossRef]

3. Perry, W.B.; Christiansen, T.A.; Perry, S.A. Response of Soil and Leaf Litter Microarthropods to Forest Application of Diflubenzuron. Ecotoxicology 1997, 6, 87-99. [CrossRef]

4. Niemelä, J.; Haila, Y.; Punttila, P. The Importance of Small-scale Heterogeneity in Boreal Forests: Variation in Diversity in Forest-floor Invertebrates Across the Succession Gradient. Ecography 1996, 19, 352-368. [CrossRef]

5. Kremen, C.; Colwell, R.K.; Erwin, T.L.; Murphy, D.D.; Noss, R.A.; Sanjayan, M.A. Terrestrial Arthropod Assemblages: Their use in Conservation Planning. Conserv. Biol. 1993, 796-808. [CrossRef]

6. Cameron, E.A.; Reeves, R.M. Carabidae (Coleoptera) Associated with Gypsy Moth, Lymantria Dispar (L.) (Lepidoptera: Lymantriidae), Populations Subjected to Bacillus Thuringiensis Berliner Treatments in Pennsylvania. Can. Entomol. 1990, 122, 123-129. [CrossRef]

7. DuDevoir, D.S.; Reeves, R.M. Feeding Activity of Carabid Beetles and Spiders on Gypsy Moth Larvae (Lepidoptera: Lymantriidae) at High-Density Prey Populations. J. Entomol. Sci. 1990, 25, 341-356. [CrossRef]

8. Jennings, D.T.; Dimond, J.B.; Watt, B.A. Population Densities of Spiders (Araneae) and Spruce Budworms (Lepidoptera, Tortricidae) on Foliage of Balsam Fir and Red Spruce in East-Central Maine. J. Arachnol. J. Ėntomol. Sci. 1990, 25, 341-356.

9. Mason, R.R.; Jennings, D.T.; Paul, H.G.; Wickman, B.E. Patterns of Spider (Araneae) Abundance during an Outbreak of Western Spruce Budworm (Lepidoptera: Tortricidae). Environ. Entomol. 1997, 26, 507-518. [CrossRef]

10. Raymond, B.; Vanbergen, A.; Watt, A.; Hartley, S.E.; Cory, J.S.; Hails, R.S. Escape from Pupal Predation as a Potential Cause of Outbreaks of the Winter Moth, Operophtera Brumata. Oikos 2002, 98, 219-228. [CrossRef]

11. Reichle, D.E. The Role of Soil Invertebrates in Nutrient Cycling. Ecol. Bull. 1977, 25, 145-156.

12. Petal, J. The role of ants in ecosystems. In Production Ecology of Ants and Termites; Brian, M.V., Ed.; Cambridge University Press: London, UK, 1978; pp. 293-325. 
13. Petersen, H.; Luxton, M. A Comparative Analysis of Soil Fauna Populations and their Role in Decomposition Processes. Oikos 1982, 39, 288. [CrossRef]

14. Klironomos, J.N.; Kendrick, W.B. Stimulative Effects of Arthropods on Endomycorrhizas of Sugar Maple in the Presence of Decaying Litter. Funct. Ecol. 1995, 9, 528. [CrossRef]

15. Webb, D.P. Regulation of deciduous forest litter decomposition by soil arthropod feces. In The Role of Arthropods in Forest Ecosystems; Springer: Berlin/Heidelberg, Germany, 1977; pp. 57-69.

16. Pardeshi, M.; Prusty, B.K. Termites as Ecosystem Engineers and Potentials for Soil Restoration. Curr. Sci. $2010,99,11$.

17. Jouquet, P.; Dauber, J.; Lagerlöf, J.; Lavelle, P.; Lepage, M. Soil Invertebrates as Ecosystem Engineers: Intended and Accidental Effects on Soil and Feedback Loops. Appl. Soil Ecol. 2006, 32, 153-164. [CrossRef]

18. Ulyshen, M.D. Wood Decomposition as Influenced by Invertebrates. Biol. Rev. 2016, 91, 70-85. [CrossRef]

19. Chen, B.; Wise, D.H. Bottom-up Limitation of Predaceous Arthropods in a Detritus-based Terrestrial Food Web. Ecology 1999, 80, 761-772. [CrossRef]

20. Moskowitz, N.A.; Dorritie, B.; Fay, T.; Nieves, O.C.; Vidoudez, C.; Cambridge Rindge and Latin 2017 Biology Class; Masconomet 2017 Biotechnology Class; Fischer, E.K.; Trauger, S.A.; Coloma, L.A.; et al. Land use Impacts Poison Frog Chemical Defenses through Changes in Leaf Litter Ant Communities. Neotrop. Biodivers. 2020, 6, lxxv-xvii. [CrossRef]

21. Langor, D.W.; Spence, J.R. Arthropods as Ecological Indicators of Sustainability in Canadian Forests. For. Chron. 2006, 82, 344-350. [CrossRef]

22. McGeoch, M.A.; Chown, S.L. Scaling Up the Value of Bioindicators. Trends Ecol. Evol. 1998, 13, 46-47. [CrossRef]

23. Rainio, J.; Niemelä, J. Ground Beetles (Coleoptera: Carabidae) as Bioindicators. Biodivers. Conserv. 2003, 12, 487-506. [CrossRef]

24. Andersen, A.N.; Majer, J.D. Ants show the Way Down Under: Invertebrates as Bioindicators in Land Management. Front. Ecol. Environ. 2004, 2, 291-298. [CrossRef]

25. Buddle, C.M.; Langor, D.W.; Pohl, G.R.; Spence, J.R. Arthropod Responses to Harvesting and Wildfire: Implications for Emulation of Natural Disturbance in Forest Management. Biol. Conserv. 2006, 128, 346-357. [CrossRef]

26. Greenberg, C.H.; McGrane, A. A Comparison of Relative Abundance and Biomass of Ground-Dwelling Arthropods Under Different Forest Management Practices. For. Ecol. Manag. 1996, 89, 31-41. [CrossRef]

27. Cole, R.J.; Holl, K.D.; Zahawi, R.A.; Wickey, P.; Townsend, A.R. Leaf Litter Arthropod Responses to Tropical Forest Restoration. Ecol. Evol. 2016, 6, 5158-5168. [CrossRef]

28. Vasconcelos, H.L.; Pacheco, R.; Silva, R.C.; Vasconcelos, P.B.; Lopes, C.T.; Costa, A.N.; Bruna, E.M. Dynamics of the Leaf-Litter Arthropod Fauna Following Fire in a Neotropical Woodland Savanna. PLoS ONE 2009, 4, e7762. [CrossRef]

29. Nakamura, A.; Proctor, H.; Catterall, C.P. Using Soil and Litter Arthropods to Assess the State of Rainforest Restoration. Ecol. Manag. Restor. 2003, 4, S20-S28. [CrossRef]

30. Nakamura, A.; Catterall, C.P.; House, A.P.; Kitching, R.L.; Burwell, C.J. The use of Ants and Other Soil and Litter Arthropods as Bio-Indicators of the Impacts of Rainforest Clearing and Subsequent Land Use. J. Insect Conserv. 2007, 11, 177-186. [CrossRef]

31. Ulyshen, M.D.; Hanula, J.L. Litter-Dwelling Arthropod Abundance Peaks Near Coarse Woody Debris in Loblolly Pine Forests of the Southeastern United States. Fla. Entomol. 2009, 92, 163-164. [CrossRef]

32. Smith, M.A.; Boyd, A.; Chan, A.; Clout, S.; des Brisay, P.; Dolson, S.; Eagalle, T.; Espinola, S.; Fairweather, A.; Frank, S. Investigating the Effect of Forestry on Leaf-Litter Arthropods (Algonquin Park, Ontario, Canada). PLoS ONE 2017, 12, e0178568. [CrossRef]

33. Lange, M.; Weisser, W.W.; Gossner, M.M.; Kowalski, E.; Türke, M.; Joner, F.; Fonseca, C.R. The Impact of Forest Management on Litter-Dwelling Invertebrates: A Subtropical-temperate Contrast. Biodivers. Conserv. 2011, 20, 2133-2147. [CrossRef]

34. Meyer, S.; Rusterholz, H.; Salamon, J.; Baur, B. Leaf Litter Decomposition and Litter Fauna in Urban Forests: Effect of the Degree of Urbanisation and Forest Size. Pedobiologia 2020, 78, 150609. [CrossRef]

35. Tóth, Z.; Hornung, E. Taxonomic and Functional Response of Millipedes (Diplopoda) to Urban Soil Disturbance in a Metropolitan Area. Insects 2020, 11, 25. [CrossRef] [PubMed]

36. Nascimento, E.; Reis, F.; Chichorro, F.; Canhoto, C.; Gonçalves, A.L.; Simões, S.; Sousa, J.P.; da Silva, P.M. Effects of Management on Plant Litter Traits and Consequences for Litter Mass Loss and Collembola Functional Diversity in a Mediterranean Agro-Forest System. Pedobiologia 2019, 75, 38-51. [CrossRef]

37. Peng, M.; Hung, Y.; Liu, K.; Neoh, K. Landscape Configuration and Habitat Complexity Shape Arthropod Assemblage in Urban Parks. Sci. Rep. 2020, 10, 16043. [CrossRef]

38. Oxbrough, A.; French, V.; Irwin, S.; Kelly, T.C.; Smiddy, P.; O’Halloran, J. Can Mixed Species Stands Enhance Arthropod Diversity in Plantation Forests? For. Ecol. Manag. 2012, 270, 11-18. [CrossRef]

39. Kattan, G.H.; Correa, D.; Escobar, F.; Medina, C. Leaf-litter Arthropods in Restored Forests in the Colombian Andes: A Comparison between Secondary Forest and Tree Plantations. Restor. Ecol. 2006, 14, 95-102. [CrossRef]

40. Bird, S.B.; Coulson, R.N.; Fisher, R.F. Changes in Soil and Litter Arthropod Abundance Following Tree Harvesting and Site Preparation in a Loblolly Pine (Pinus Taeda L.) Plantation. For. Ecol. Manag. 2004, 202, 195-208. [CrossRef]

41. Bird, S.; Coulson, R.N.; Crossley, D.A., Jr. Impacts of Silvicultural Practices on Soil and Litter Arthropod Diversity in a Texas Pine Plantation. For. Ecol. Manag. 2000, 131, 65-80. [CrossRef]

42. Cicort-Lucaciu, A.; Cupsa, D.; Sucea, F.; Ferenti, S.; Covaciu-Marcov, S. Litter-Dwelling Invertebrates in Natural and Plantation Forests in the Southern Carpathians, Romania. Balt. For. 2020, 26, 1. [CrossRef] 
43. Ingle, K.; Kaur, H.; Gallé-Szpisjak, N.; Bürgés, J.; Szabó, Á.; Gallé, R. Winter-Active Spider Fauna is Affected by Plantation Forest Type. Environ. Entomol. 2020, 49, 601-606. [CrossRef] [PubMed]

44. Niemelä, J. Management in Relation to Disturbance in the Boreal Forest. For. Ecol. Manag. 1999, 115, 127-134. [CrossRef]

45. Seymour, R.S.; White, A.S.; Philip, G.D. Natural Disturbance Regimes in Northeastern North America-evaluating Silvicultural Systems using Natural Scales and Frequencies. For. Ecol. Manag. 2002, 155, 357-367. [CrossRef]

46. Herrera-Alvarez, X.; Blanco, J.A.; Imbert, J.B.; Alvarez, W.; Rivadeneira-Barba, G. Coarse Woody Debris' Invertebrate Community is Affected Directly by Canopy Type and Indirectly by Thinning in Mixed Scots Pine-European Beech Forests. Forests 2020, 11, 975. [CrossRef]

47. Chen, J.; Franklin, J.F.; Spies, T.A. Contrasting Microclimates among Clearcut, Edge, and Interior of Old-Growth Douglas-Fir Forest. Agric. For. Meteorol. 1993, 63, 219-237. [CrossRef]

48. Van Wilgenburg, S.L.; Mazerolle, D.F.; Hobson, K.A. Patterns of Arthropod Abundance, Vegetation, and Microclimate at Boreal Forest Edge and Interior in Two Landscapes: Implications for Forest Birds. Ecoscience 2001, 8, 454-461. [CrossRef]

49. Seastedt, T.R.; Crossley, D.A., III. Microarthropod Response Following Cable Logging and Clear-cutting in the Southern Appalachians. Ecology 1981, 62, 126-135. [CrossRef]

50. Burghouts, T.; Ernsting, G.; Korthals, G.; De Vries, T. Litterfall, Leaf Litter Decomposition and Litter Invertebrates in Primary and Selectively Logged Dipterocarp Forest in Sabah, Malaysia. Philosophical Transactions of the Royal Society of London. Ser. B Biol. Sci. $1992,335,407-416$.

51. Kriska, D.J.; Lee, H.J.; Krebs, R.A. Effect of Oak Barren Restoration on Carabidae (Coleoptera) within a Kame-Kettle Bog System. Ecol. Restor. 2020, 38, 24-31. [CrossRef]

52. Simard, J.R.; Fryxell, J.M. Effects of Selective Logging on Terrestrial Small Mammals and Arthropods. Can. J. Zool. 2003, 81, 1318-1326. [CrossRef]

53. Turner, E.C.; Foster, W.A. The Impact of Forest Conversion to Oil Palm on Arthropod Abundance and Biomass in Sabah, Malaysia. J. Trop. Ecol. 2009, 25, 23-30. [CrossRef]

54. Castro, A.; Wise, D.H. Influence of Fallen Coarse Woody Debris on the Diversity and Community Structure of Forest-Floor Spiders (Arachnida: Araneae). For. Ecol. Manag. 2010, 260, 2088-2101. [CrossRef]

55. Grevé, M.E.; Hager, J.; Weisser, W.W.; Schall, P.; Gossner, M.M.; Feldhaar, H. Effect of Forest Management on Temperate Ant Communities. Ecosphere 2018, 9, e02303. [CrossRef]

56. Preece, N.D.; Van Oosterzee, P.; Lawes, M.J. Planting Methods Matter for Cost-effective Rainforest Restoration. Ecol. Manag. Restor. 2013, 14, 63-66. [CrossRef]

57. Bechara, F.C.; Dickens, S.J.; Farrer, E.C.; Larios, L.; Spotswood, E.N.; Mariotte, P.; Suding, K.N. Neotropical Rainforest Restoration: Comparing Passive, Plantation and Nucleation Approaches. Biodivers. Conserv. 2016, 25, 2021-2034. [CrossRef]

58. Stone, M.J.; Shoo, L.; Stork, N.E.; Sheldon, F.; Catterall, C.P. Recovery of Decomposition Rates and Decomposer Invertebrates during Rain Forest Restoration on Disused Pasture. Biotropica 2020, 52, 230-241. [CrossRef]

59. Jiménez-Carmona, E.; Herrera-Rangel, J.; Renjifo, L.M.; Armbrecht, I. Restoration of Riparian Forest Corridors: Eight Years Monitoring the Diversity of Soil Ants in an Andean Rural Landscape. Insect Conserv. Divers. 2020, 13, 384-392. [CrossRef]

60. Belshaw, R.; Bolton, B. The Effect of Forest Disturbance on the Leaf Litter Ant Fauna in Ghana. Biodivers. Conserv. 1993, 2, 656-666. [CrossRef]

61. Ottermanns, R.; Hopp, P.W.; Guschal, M.; dos Santos, G.P.; Meyer, S.; Roß-Nickoll, M. Causal Relationship between Leaf Litter Beetle Communities and Regeneration Patterns of Vegetation in the Atlantic Rainforest of Southern Brazil (Mata Atlântica). Ecol. Complex. 2011, 8, 299-309. [CrossRef]

62. Vergílio, P.C.B.; Knoll, F.R.N.; Barreto, D.M.; Dinardi, N.M.; Ueda, M.Y.; Cavassan, O. Effect of Brushwood Transposition on the Leaf Litter Arthropod Fauna in a Cerrado Area. Revista Brasileira Ciência Solo 2013, 37, 1158-1163. [CrossRef]

63. Caterino, M.S.; Langton-Myers, S.S. Long-Term Population Persistence of Flightless Weevils (Eurhoptus Pyriformis) Across Oldand Second-Growth Forests Patches in Southern Appalachia. BMC Evol. Biol. 2018, 18, 1-16. [CrossRef] [PubMed]

64. Caterino, M.S.; Vásquez-Vélez, L.M.; Myers, S.S. On the Conservation Value of Second-Growth Forests for Leaf-Litter Inhabiting Beetles. Insect Syst. Divers. 2017, 1, 20-28. [CrossRef]

65. Meloni, F.; Varanda, E.M. Litter and Soil Arthropod Colonization in Reforested Semi-deciduous Seasonal Atlantic Forests. Restor. Ecol. 2015, 23, 690-697. [CrossRef]

66. Rieske, L.K.; Buss, L.J. Effects of Gypsy Moth Suppression Tactics on Litter-and Ground-Dwelling Arthropods in the Central Hardwood Forests of the Cumberland Plateau. For. Ecol. Manag. 2001, 149, 181-195. [CrossRef]

67. Ulyshen, M.D. Arthropod Vertical Stratification in Temperate Deciduous Forests: Implications for Conservation-Oriented Management. For. Ecol. Manag. 2011, 261, 1479-1489. [CrossRef]

68. Kreutzweiser, D.; Dutkiewicz, D.; Capell, S.; Sibley, P.; Scarr, T. Changes in Streamside Riparian Forest Canopy and Leaf Litter Nutrient Flux to Soils during an Emerald Ash Borer Infestation in an Agricultural Landscape. Biol. Invasions 2020, 22, 1865-1878. [CrossRef]

69. Woodworth, G.R.; Ward, J.N.; Carr, D.E. Exotic Tree and Shrub Invasions Alter Leaf-Litter Microflora and Arthropod Communities. Oecologia 2020, 193, 177-187. [CrossRef] 
70. Oliver, I.; Mac Nally, R.; York, A. Identifying Performance Indicators of the Effects of Forest Management on Ground-Active Arthropod Biodiversity using Hierarchical Partitioning and Partial Canonical Correspondence Analysis. For. Ecol. Manag. 2000, 139, 21-40. [CrossRef]

71. Fule, P.Z.; Ramos-Gómez, M.; Cortés-Montaño, C.; Miller, A.M. Fire Regime in a Mexican Forest Under Indigenous Resource Management. Ecol. Appl. 2011, 21, 764-775. [CrossRef]

72. Whitehead, P.J.; Bowman, D.M.; Preece, N.; Fraser, F.; Cooke, P. Customary use of Fire by Indigenous Peoples in Northern Australia: Its Contemporary Role in Savanna Management. Int. J. Wildland Fire 2003, 12, 415-425. [CrossRef]

73. Shaffer, L.J. Indigenous Fire use to Manage Savanna Landscapes in Southern Mozambique. Fire Ecol. 2010, 6, 43-59. [CrossRef]

74. Kimmerer, R.W.; Lake, F.K. The Role of Indigenous Burning in Land Management. J. For. 2001, 99, 36-41.

75. Scheller, R.M.; Mladenoff, D.J.; Crow, T.R.; Sickley, T.A. Simulating the Effects of Fire Reintroduction Versus Continued Fire Absence on Forest Composition and Landscape Structure in the Boundary Waters Canoe Area, Northern Minnesota, USA. Ecosystems 2005, 8, 396-411. [CrossRef]

76. Buddle, C.M.; Spence, J.R.; Langor, D.W. Succession of Boreal Forest Spider Assemblages Following Wildfire and Harvesting. Ecography 2000, 23, 424-436. [CrossRef]

77. Gandhi, K.J.; Spence, J.R.; Langor, D.W.; Morgantini, L.E. Fire Residuals as Habitat Reserves for Epigaeic Beetles (Coleoptera: Carabidae and Staphylinidae). Biol. Conserv. 2001, 102, 131-141. [CrossRef]

78. Glenn-Lewin, D.C.; Peet, R.K.; Veblen, T.T. Plant Succession: Theory and Prediction; Springer Science \& Business Media: Berlin/Heidelberg, Germany, 1992.

79. Haimi, J.; Fritze, H.; Moilanen, P. Responses of Soil Decomposer Animals to Wood-Ash Fertilisation and Burning in a Coniferous Forest Stand. For. Ecol. Manag. 2000, 129, 53-61. [CrossRef]

80. Buffington, J.D. Soil Arthropod Populations of the New Jersey Pine Barrens as Affected by Fire. Ann. Entomol. Soc. Am. 1967, 60, 530-535. [CrossRef]

81. York, A. Long-term Effects of Frequent Low-intensity Burning on Ant Communities in Coastal Blackbutt Forests of Southeastern Australia. Austral Ecol. 2000, 25, 83-98. [CrossRef]

82. Yanovsky, V.M.; Kiselev, V.V. Response of the endemic insect fauna to fire damage in forest ecosystems. In Fire in Ecosystems of Boreal Eurasia; Goldhammer, J.G., Furyaev, V.V., Eds.; Kluwer Academic Publishers: Amsterdam, The Netherlands, 1996; pp. 409-413.

83. Mitchell, R.G. Effects of prescribed fire on insect pests. In Natural and Prescribed Fire in Pacific Northwest Forests; Walstad, J.D., Radosevich, S.R., Sandberg, D.V., Eds.; Oregon State University Press: Corvallis, OR, USA, 1990; pp. 111-116.

84. Verble-Pearson, R.M. Effects of Fire Intensity on Litter Arthropod Communities in Ozark Oak Forests, Arkansas, USA. Am. Midl. Nat. 2014, 172, 14-24. [CrossRef]

85. Swengel, A.B. A Literature Review of Insect Responses to Fire, Compared to Other Conservation Managements of Open Habitat. Biodivers. Conserv. 2001, 10, 1141-1169. [CrossRef]

86. Moretti, M.; Obrist, M.K.; Duelli, P. Arthropod Biodiversity After Forest Fires: Winners and Losers in the Winter Fire Regime of the Southern Alps. Ecography 2004, 27, 173-186. [CrossRef]

87. Apigian, K.O.; Dahlsten, D.L.; Stephens, S.L. Fire and Fire Surrogate Treatment Effects on Leaf Litter Arthropods in a Western Sierra Nevada Mixed-Conifer Forest. For. Ecol. Manag. 2006, 221, 110-122. [CrossRef]

88. Paquin, P.; Coderre, D. Deforestation and Fire Impact on Edaphic Insect Larvae and Other Macroarthropods. Environ. Entomol. 1997, 26, 21-30. [CrossRef]

89. Siemann, E.; Haarstad, J.; Tilman, D. Short-Term and Long-Term Effects of Burning on Oak Savanna Arthropods. Am. Midl. Nat. 1997, 137, 349. [CrossRef]

90. Niwa, C.G.; Peck, R.W. Influence of Prescribed Fire on Carabid Beetle (Carabidae) and Spider (Araneae) Assemblages in Forest Litter in Southwestern Oregon. Environ. Entomol. 2002, 31, 785-796. [CrossRef]

91. Abbott, I. Changes in the Abundance and Activity of Certain Soil and Litter Fauna in the Jarrah Forest of Western Australia After a Moderate Intensity Fire. Soil Res. 1984, 22, 463-469. [CrossRef]

92. Moretti, M.; Duelli, P.; Obrist, M.K. Biodiversity and Resilience of Arthropod Communities After Fire Disturbance in Temperate Forests. Oecologia 2006, 149, 312-327. [CrossRef]

93. Holliday, N.J. The Carabid Fauna (Coleoptera: Carabidae) during Postfire Regeneration of Boreal Forest: Properties and Dynamics of Species Assemblages. Can. J. Zool. 1992, 70, 440-452. [CrossRef]

94. Collett, N. Short and Long-Term Effects of Prescribed Fires in Autumn and Spring on Surface-Active Arthropods in Dry Sclerophyll Eucalypt Forests of Victoria. For. Ecol. Manag. 2003, 182, 117-138. [CrossRef]

95. Baker, S.C.; Richardson, A.M.; Seeman, O.D.; Barmuta, L.A. Does Clearfell, Burn and Sow Silviculture Mimic the Effect of Wildfire? A Field Study and Review using Litter Beetles. For. Ecol. Manag. 2004, 199, 433-448. [CrossRef]

96. Beaudry, S.; Duchesne, L.C.; Côté, B. Short-Term Effects of Three Forestry Practices on Carabid Assemblages in a Jack Pine Forest. Can. J. For. Res. 1997, 27, 2065-2071. [CrossRef]

97. Coleman, T.W.; Rieske, L.K. Arthropod Response to Prescription Burning at the Soil-litter Interface in Oak-pine Forests. For. Ecol. Manag. 2006, 233, 52-60. [CrossRef] 
98. Klironomos, J.N.; Kendrick, B. Relationships among Microarthropods, Fungi, and their Environment. Plant Soil 1995, $170,183-197$. [CrossRef]

99. Fritze, H.; Smolander, A.; Levula, T.; Kitunen, V.; Mälkönen, E. Wood-Ash Fertilization and Fire Treatments in a Scots Pine Forest Stand: Effects on the Organic Layer, Microbial Biomass, and Microbial Activity. Biol. Fertil. Soils 1994, 17, 57-63. [CrossRef] 